4. Plamper A, Goldmann G, Lingohr P, Horneff S, Dohmen J, Oldenburg $J$, Rheinwalt KP. First case of laparoscopic mini-gastric bypass for the treatment of morbid obesity in severe haemophilia A. Hamostaseologie 2019;39:208-210.
5. Türk Hematoloji Derneği. Hemaofili Tanıve Tedavi Kılavuzu. Sürüm 1, Temmuz 2011. Ankara, Türk Hematoloji Derneği, 2011.

${ }^{\circ}$ Copyright 2020 by Turkish Society of Hematology

Turkish Journal of Hematology, Published by Galenos Publishing House

\title{
A Novel Coincidence: Essential Thrombocythemia with Facioscapulohumeral Muscular Dystrophy
}

\author{
Yeni Bir Birliktelik: Esansiyel Trombositemi ve Fasioskapulohumeral Musküler Distrofi
}

\author{
(D) Ceren Hangül1, (D) Orhan Kemal Yücel2, (D) Aslı Toylu³, (D) Hilmi Uysal4, (D) Sibel Berker Karaüzüm¹ \\ ${ }^{1}$ Akdeniz University Faculty of Medicine, Department of Medical Biology and Genetics, Antalya, Turkey \\ ${ }^{2}$ Akdeniz University Faculty of Medicine, Department of Hematology, Antalya, Turkey \\ ${ }^{3}$ Akdeniz University Faculty of Medicine, Department of Medical Genetics, Antalya, Turkey \\ ${ }^{4}$ Akdeniz University Faculty of Medicine, Department of Neurology, Antalya, Turkey
}

\section{To the Editor,}

Essential thrombocythemia (ET) is a myeloproliferative disorder with elevated numbers of thrombocytes and facioscapulohumeral muscular dystrophy (FSHD) is the third most common dystrophy among all dystrophies. In this paper, we report a novel case of FSHD coinciding with ET.

The male FSHD patient was diagnosed at the age of 17 with difficulty of raising his arms. He had 4q35 D4Z4 repeat contraction. A neurological examination revealed positive facial involvement and scapula alata; right and left shoulder flexion $4+$; right forearm flexion $4+$; left forearm flexion $3+$; right and left hip flexion $4+$; remaining muscle strengths $5+$. Mild involvement and loss of power were seen in the extensor indicis, peroneal muscles, and abdominal muscles. When the patient was 67 years old, he was admitted to the hematology clinic with facial redness and increased platelet count $\left(1,200,000 / \mathrm{mm}^{3}\right)$ without hepatosplenomegaly.

Since myeloproliferative neoplasms (MPNs) are frequently related to somatic mutations of the JAK2, MPL, and CALR genes, the patient's blood sample was analyzed for the hot-spot mutations of these genes. The exon 10 region of the MPL gene was analyzed for p.W515K/L mutation and the exon 9 region of the $C A L R$ gene was analyzed for insertion/deletion mutations with PCR/sequencing methods. The exon 14 region of the JAK2 (Janus kinase 2) gene was investigated for p.V617F (c.1849G>T) mutation by quantitative real-time PCR using plasmids of wild type and mutant alleles. There was no mutation in the target regions of the MPL and CALR genes. In the exon 14 region of the JAK2 gene, p.V617F (c.1849G>T) mutation was detected with $28 \%$ allele burden (Figure 1).

His child was also investigated for the JAK2 p.V617F (c.1849G>T) mutation and was found to be negative. Finally, the patient was diagnosed with high-risk ET because of being aged $>60$ years with JAK2 mutation, and hydroxyurea and low-dose aspirin were started.

In this case, the presence of the JAK2 p.V617F mutation confirmed the diagnosis of ET. There has been no report on the co-occurrence of FSHD with MPNs including ET and JAK2 p.V617F mutation, and this is the first such case in the literature. Recently, a number of reports indicated that some germ-line DNA variants may predispose to MPNs with JAK2 p.V617F mutation [1].

FSHD patients are prone to develop other systemic diseases, especially malignancies [2], via re-expression of the DUX4 gene that allows cancer cells to escape immune surveillance [3]. In addition, myeloid cells (including thrombocytes) and skeletal 

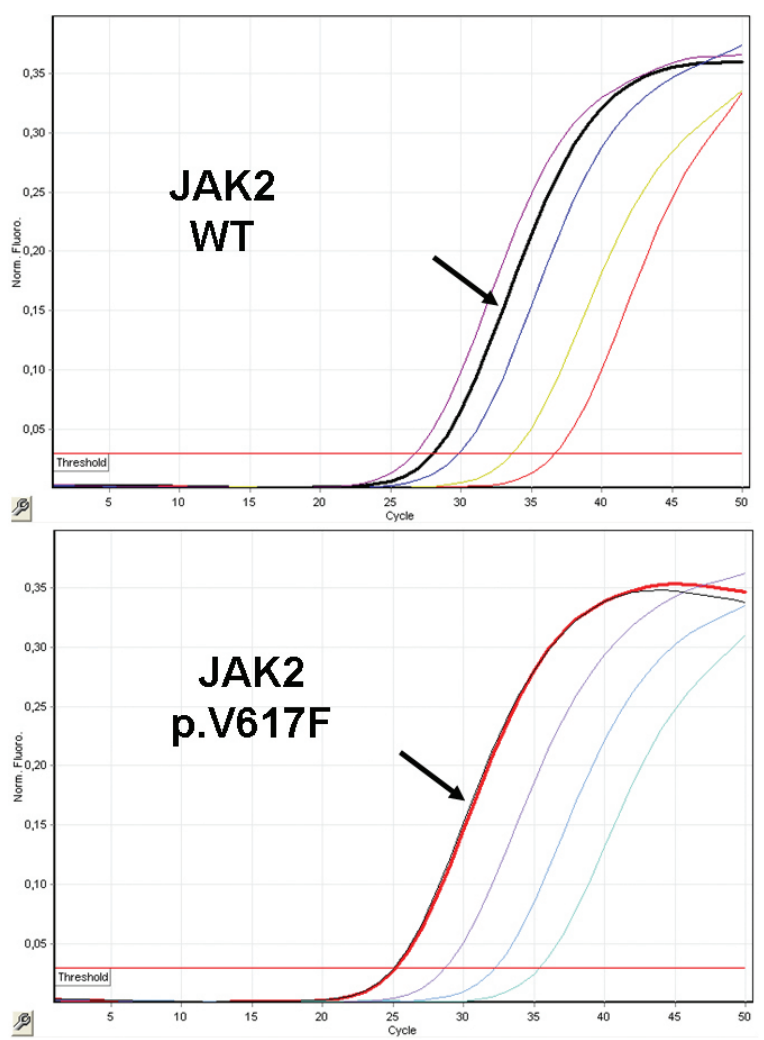

Figure 1. Visual representation of the patient's quantitative realtime PCR results for the JAK2 gene.

muscle cells originate from the mesoderm. It has been shown that the JAK/STAT pathway is responsible for the proliferation and differentiation of both myeloblasts and myoblast cells $[4,5]$. Our case might indicate a common mechanism responsible for the development of FSHD and MPNs. In addition to the effect of DUX4, since JAK signaling has important functions in the development of both skeletal muscle and thrombocytes, we propose that this co-occurrence signifies the importance of focusing on the role of the JAK/STAT pathway for FSHD pathophysiology, which can also contribute to the molecular mechanisms of ET.

Keywords: Essential thrombocythemia, ET, Facioscapulohumeral Muscular Dystrophy, FSHD, JAK2 p.V617F mutation
Anahtar Sözcükler: Esansiyel trombositemi, ET, Fasioskapulohumeral Musküler Distrofi, FSHD, JAK2 p.V617F mutasyonu

Informed Consent: Informed consent had been received from the patient.

\section{Authorship Contributions}

Design: C.H., S.B.K.; Data Collection or Processing: A.T., O.K.Y., H.U., C.H., S.B.K.; Analysis or Interpretation: C.H., S.B.K., A.T., O.K.Y.; Writing: H.U.

Conflict of Interest: The authors declare no conflict of interest. All procedures performed in this study were in accordance with the ethical standards of the Akdeniz University Institutional Ethical Committee (Decision Number: 284, Date: 28.10.2015) and with the 1964 Declaration of Helsinki and its later amendments or comparable ethical standards.

This study was funded by the Akdeniz University Research Foundation.

\section{References}

1. Hinds DA, Barnholt KE, Mesa RA, Kiefer AK, Do CB, Eriksson N, Mountain JL, Francke U, Tung JY, Nguyen HM, Zhang H, Gojenola L, Zehnder JL, Gotlib J. Germ line variants predispose to both JAK2 V617F clonal hematopoiesis and myeloproliferative neoplasms. Blood 2016;128:1121-1128.

2. Dmitriev P, Kairov U, Robert T, Barat A, Lazar V, Carnac G, Laoudj-Chenivesse $D$, Vassetzky YS. Cancer-related genes in the transcription signature of facioscapulohumeral dystrophy myoblasts and myotubes. J Cell Mol Med 2014;18:208-217.

3. Chew GL, Campbell AE, De Neef E, Sutliff NA, Shadle SC, Tapscott SJ, Bradley RK. DUX4 suppresses MHC class I to promote cancer immune evasion and resistance to checkpoint blockade. Dev Cell 2019;50:658-671.

4. Trenerry MK, Della Gatta PA, Cameron-Smith D. JAK/STAT signaling and human in vitro myogenesis. BMC Physiol 2011;11:6.

5. Wang $K$, Wang $C$, Xiao $F$, Wang $H$, Wu Z. JAK2/STAT2/STAT3 are required for myogenic differentiation. J Biol Chem 2008;283:34029-34036.

๑Copyright 2020 by Turkish Society of Hematology

Turkish Journal of Hematology, Published by Galenos Publishing House

Address for Correspondence/Yazışma Adresi: Sibel Berker Karaüzüm, PhD, Akdeniz University Faculty of

Medicine, Department of Medical Biology and Genetics, Antalya, Turkey

Phone : +90 5327278941

E-mail : sibelberkerkarauzum@gmail.com ORCID: orcid.org/0000-0002-6338-7623
Received/Geliş tarihi: June 30, 2020 Accepted/Kabul tarihi: August 13, 2020

DOI: 10.4274/tjh.galenos.2020.2020.0363 